\title{
EXPLOITATION AND CPUE TREND OF THE SMALL PELAGIC FISHERIES IN THE SULAWESI SEA, INDONESIA
}

\author{
Lilis Sadiyah, Purwanto, and Andhika Prima Prasetyo \\ Research Center for Fisheries Management and Conservation \\ Received February 10-2012; Received in revised form December 10-2012; Accepted December 11-2012 \\ E-Mail: lilis_sadiyah@yahoo.com
}

\begin{abstract}
One of the expected benefits of the Sulu-Celebes Sea Project during its implementation is to have increased fish stocks at demonstration sites, as indicated by the Catch per Unit of Effort (CPUE). Analysis of catch and effort data of the small pelagic fisheries by using the surplus yield model was done to obtain information on the likely trend of CPUE for the last ten years. By using the pajeko as the standardized fishing gear the trend of CPUE has been calculated. Between 2000-2005, the trend of production (catch), effort and CPUE followed the general pattern of the exploited fisheries that already fully exploited, where the increasing trend of effort was not followed by the increasing catch. On the other hand, the trend of CPUE is decreased. In the following years, the trend of both catch and CPUE do not follow the general pattern of the exploited fisheries. The trend of catch, effort and CPUE has likely been stable, indicating that the fishery in this period has been leveled-off. The status of exploitation of the small pelagic fish resources in the Indonesian Sulawesi Sea is demermined by the MSY level that has likely been surpassed during the period 2003-2004. Therefore with the increasing effort in the following year the trend of catch was relatively stable. It is likely that the small pelagic fish stock in the Indonesian Sulawesi Sea might be 'fully exploited'.
\end{abstract}

\section{Keywords : Exploitation, CPUE, Small Pelagic Fisheries, Sulawesi Sea}

\section{INTRODUCTION}

Different with some terrestrial resources consisted of relatively sedentary species and visible, the fish resources are invisible as they occupy habitat in the form of water body. But the fish resources provide living animal that are always moving and migrating in the effort of adjustment to fulfill their metabolic requirement suitable to the dynamic of biophysical environment. Most of the fish resources available in the waters around the districts located in the northern part of East Kalimantan Province or western part the Sulawesi Sea carry out their movement and migration from one place to another following the oceanographic conditions. Because the fish resource provides living animal, therefore they are belong to that so called renewable resources. Although, these resources could sustainably exploit when exploitation or fishing activities carry out do not exceed their ability to recover.

The classical method of monitoring changes in fish stock abundance has been the use of catch and effort statistics from the commercial fishery. This has two big advantages as it can be cheap, since the basic data may be collected for other purposes, and because it may be based on the operations of hundreds of vessels, and tens of thousands or more fishing operations, the sample variance can be very small (Ulltang, 1977).
The fish resources in the waters around the districts and City of Tarakan have been exploited for years. Unfortunately, data and information especially basic data of catch and effort as well as some biological aspects related to the life history and population dynamics needed for stock assessment purposes, are considered inappropriate. In line with the increasing demand on the fish commodities either local, domestic and export, most of effort in increasing fish production are likely required research support regarding fish stock and its methodologies for rational exploitation so that the catches obtained could be maintained optimally and sustainably. It is therefore for rational and sustainable exploitation some management measures would be needed, otherwise the resources might be overfished and in turn the fisheries could be collapsed.

This paper attempts to assess the present status of the small pelagic fish resources exploitation in the waters of the Sulawesi Sea Fisheries Management Area in the framework of the Sulu-Celebes Sea Sustainable Fisheries Management Project of the United Nation Office for Project Services (UNOPS) Project No.: 72595. One of the expected benefits of the Sulu-Celebes Project during its implementation from 2010-2014 is to have "increased fish stocks at demonstration sites (5-10 percent increase)", as indicated by the Catch per Unit of Effort (CPUE). Trend of CPUE presented in this paper will provide one of the baselines data. 


\section{MATERIALS AND METHODS}

In relation with the availability of statistical catch and effort data, data analysis carried out cover serial data of 2000-2009. Analysis of catch and effort data was focused to the small pelagic fish resources and its fishing gears used. As it is known that the fish resources in the waters of the Indonesian Sulawesi Sea has been exploited using a number of difference fishing gear with difference catchability. For the application of the surplus yield model, based on the available data a standardization of fishing gears need to be carried out through the estimation of fishing power index (FPI). With this work, the calculated annual fishing effort unit is presented in the form of equivalent with the standardized fishing gear.
The estimated FPI were calculated based on the production per unit gear, a sort of data available in the book of provincial fisheries statistics. Fishing gear with highest catch per gear having the $\mathrm{FPI}=1.000$ and assumed as a standard gear or standard effort. The FPI of other fishing gear were obtained by comparing catch per gear of a certain gear with the catch per gear that having $\mathrm{FPI}=1.000$. The annual total fishing effort was obtained through the addition of the multiplication between the number of fishing unit in a certain year and the FPI of that gear. Based on the appropriate provincial statistical data, the calculated FPI of each fishing gear for the small pelagic fisheries are presented in Table 1. The standard fishing gear for the small pelagic fishery in this analysis was mini purse seine or locally called as pajeko.

Table 1. Fishing gears and the estimated Fishing Power Index (FPI) in the waters of Indonesian Sulawesi Sea.

\begin{tabular}{llll}
\hline Fishing gear & FPI & Fishing gear & FPI \\
\hline Pajeko (mini purse seine) & 1.00 & Raft lift net & 0.31 \\
Drift gill net & 0.01 & Fixed lift net & 0.13 \\
Encircling net & 0.16 & Other lift net & 0.02 \\
Beach seine & 0.05 & & \\
\hline
\end{tabular}

The estimated FPI was based on the assumption that the same fishing gear in the period of 2000-2009 having the same catchability, same size or constant catchability which is needed for the application of the model (Pitcher \& Hart, 1982).

The final data resulted from the analysis provide basic data for the application of the Surplus Production Model (Sparre \& Venema, 1999) that lead to the identification the trend of catch, effort and catch perunit effort (CPUE) that provide indicators for sustainable development. One of the indicators for sustainable development of fish resources is the time series of stock abundance index as one of the index of abundance or catch per-unit of effort (CPUE).

\section{RESULTS}

Sulu-Celebes Sea, with its terrestrial, coastal and marine ecosystems, were located in the global center of tropical biodiversity, exemplified by more than 500 species of reef-building corals and 2500 species of marine fishes (Chou, 1997; Veron, 2000). Five species of sea turtles (Green, Hawksbill, Olive Ridley, Loggerhead \& Leatherback) and at least 22 species of marine mammals occur (GIWA, 2003). The marine fishery contributes significantly to the economies of Indonesia. Indonesia fisheries statistics indicate that North Sulawesi and East Kalimantan provide some
$11 \%$ of the total national marine fishery landings (1997) (Khan \& Fauzi, 2001). The fishery, although multispecies, is comprised predominantly by pelagic and to a lesser extent reef species.

In this study it is defined that the pelagic resources consist of large and small pelagic groups. The large pelagic species include tuna, skipjack, tuna like/ frigate mackerel and spanish mackerel, while the small pelagic include scads, chub mackerel, sardines, anchovies, trevallies and big-eye trevally.

\section{Unit Stock Identification}

From taxonomical aspect, the fish resources in the waters around Districts and City of Tarakan are diverse in species, so that for the management and optimal as well as sustainable exploitation will need a number of assessment activities in relation with life history and population dynamics of the fish resource in more detail. The ability to identify fish species and unit stock provides a first step in fish stock assessment and these will determine the following studies. If the first step is not accurate, the level of accuracy in the following steps will be diverted and will lead to under or over estimated results and these will further affect the identification of optimal level of exploitation and their management measures. 
Due to the large fishing area and high diversity of fisheries economic scales on one side, while information obtained from research results are still very limited, so that for the implementation of research activities it needs to consider the limits of unit stocks, such as geographical barrier and stock parameters such as rates of growth and mortality. Beside the stock parameters estimation that can only be carried out after a number of data and information been collected in a relatively longer time, from the distribution of fishing activities and the existing geographical barrier will lead to the identification of unit stock. In case otherwise, assumption should be made that data analyzed are originated from one unit stock. This assumption is likely valid as this is supported by the genetic analysis reported by Borsa, (2003). It is further stated that the data presented in his study failed to support Hardenberg's, (1937) hypothesis of three stocks in the western part of the Indo-Malay archipelago. Rohfritsch \& Borsa, (2005) reported that at the scale of the entire Indo-Malay archipelago, however, at least three distinct populations of $D$. russelliwere identified by the present study: (i) Arafura Sea, (ii) Sulawesi Sea and Makassar Strait and (iii) the rest of the Indo-Malay archipelago. A broadscale genetic homogeneity from the South China Sea to the Sulawesi Sea via the Java Sea and Makassar Strait have been reported by Arnaud et al. (1999), while Perrin \& Borsa, (2001) stated that the distinction of two clades within $D$. russelli is compatible with Pleistocene events that isolated the Sulawesi sea region from other areas in the Indo-Malay archipelago.

\section{Status of Small Pelagic Fisheries}

The present-day important of the maximum sustainable yield (MSY) is not so much as an objective to be rigidly followed in reaching decisions, but as a very convenient concept for use in discussing general management problems. This convenience arises because MSY serves, at least three distinct functions - a description of the facts of life regarding fish stocks in relation to exploitation, a clearly definable objective of management, and a measure of the success with which a stock is being managed (Gulland, 1983). Fishing grounds of the small pelagic fish in the waters of the Indonesian Sulawesi Sea are relatively large. This is due to the fact that beside the pajeko fishing gear operation with their high mobility, it is known that the small pelagic fish resources available in the waters are diverse with their wide distribution. From the information obtained during the survey period it was informed that some pajeko fishers operate their gear in relatively far away from the Tarakan Bay as they carry out fishing in the bordering waters area with Sabah, Malaysia.

The recorded small pelagic fish and analyzed based on the available catch and effort data were scads, trevallies, hard-tail scad, flying fish, mullets, sardine, rainbow sardines, chub mackerel, barracuda and gar-fish.

Trend of production, effort and CPUE for the small pelagic fish group recorded in the book of fisheries statistics are presented in the Table 2. From that table it is appeared that during 1999-2006, the highest production of about 30,500 tonnes was recorded in 2003 while the lowest production of around 17,000 tonnes was recorded in 2000. Different with the production, the highest annual efforts of 3,194 equivalent pajeko units (mini purse seine) occurred in 2005 and the lowest efforts of 574 units were recorded in 2000. The fluctuation of CPUE in that period were likely followed the pattern of catch, where the highest CPUE of approximately 32 tonnes/pajeko units/year was occurred in 2003, while the lowest CPUE of only 8.6 tonnes/pajeko unit/year occurred in 2005.

Based on data in Table 2, the trends of production, effort and CPUE are presented in Figure 1. From the figure it is appeared that between $2000-2005$ the trend of production (catch), effort and CPUE followed the general pattern of the exploited fisheries that already fully exploited. This is shown in the figure where the increasing trend of effort was not followed by the increasing catch. On the other hand, the CPUE decreased (Figure 1). In the following years, the trend of both catch and CPUE do not follow the general pattern of the exploited fisheries. The trends of catch, effort and CPUE have likely been stable, indicating that the fishery in this period has been level-off.

What is the recent status of exploitation of the small pelagic fish resources in the Indonesian Sulawesi Sea, it is appeared that the MSY level has likely been surpassed during the period 2003-2004. Therefore, with the increasing effort in the following year the trend of catch is likely relatively stable. It seems that the distribution of annual production points since 20052008 has already in the right hand side of the yield curve. It is likely that the present status of exploitation of the small pelagic fish is already in the state of 'fully exploited'. 
Table 2. Production (catch), effort and catch per unit of effort (CPUE) of the small pelagic fisheries in the waters of the Indonesian Sulawesi Sea Fisheries Management Area.

\begin{tabular}{cccc}
\hline Year & Catch (tonnes) & Effort ${ }^{*}$ ) & CPUE ${ }^{*}$ ) \\
\hline 2000 & 17,166 & 574 & 29.9 \\
2001 & 25,696 & 758 & 33.9 \\
2002 & 22,055 & 956 & 23.1 \\
2003 & 30,534 & 956 & 31.9 \\
2004 & 24,002 & 1,470 & 16.3 \\
2005 & 27,325 & 3,194 & 8.6 \\
2006 & 26,179 & 2,918 & 9.0 \\
2007 & 26217 & 2,550 & 10.3 \\
2008 & 26,561 & 2,888 & 9.2 \\
2009 & 26,565 & 2,920 & 9.1 \\
\hline
\end{tabular}

") Equivalent pajeko unit; ${ }^{* *}$ ) Tonnes/pajeko unit/year

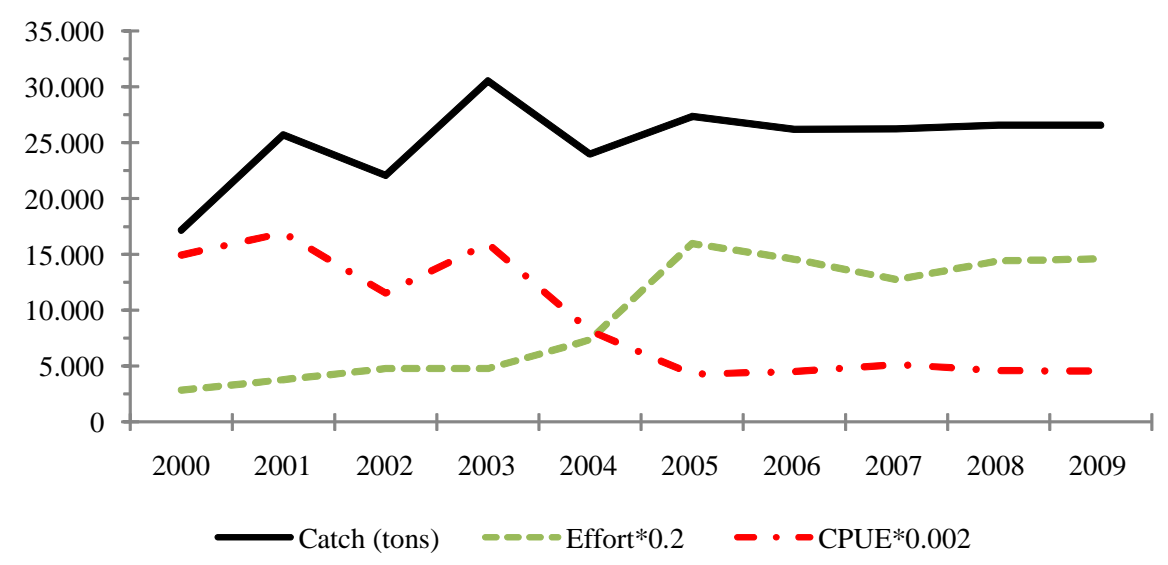

Figure 1. Trend of Production (catch), effort (pajeko unit) and catch per-unit of effort (CPUE) of the small pelagic fisheries in the waters of the Indonesian Sulawesi Sea Fisheries Management Area.

With regard to the transboundary aspects it is likely that the small pelagic fish stock (especially roundscads, Decapterus spp.) in the waters of Indonesian Sulawesi Sea forming one unit stock. As it is known that the roundscads, the most abundance and economically important small pelagic fish provide a relatively higher migratory species compare with the demersal fish. This phenomenon indicates that their exploitation forming a shared stock and consequently this resource has to be collaboratively managed. Information that has to be available will include their spawning ground, migratory pathway and some other population parameters.

\section{Trend of Catch Composition of the Small Pelagic Fisheries}

The occurring changes in species composition of fish caught in a certain waters reflecting a picture of the arising interactions that happening in a dynamic community as a result of the existence of fish population and a very dynamic nature of marine environment. These interactions can occur in form of predator-prey relationship or food competition.

From the result of the small pelagic resources data analysis in the waters of the Indonesian Sulawesi Sea it was found that the annual catch of the species group shows a slightly different trend. With the assumption that these production (catch) data were proportional with the abundance of the fish resource in the sea, the occurring catch fluctuation is likely a response from the small pelagic fish community on the disturbing factors from outside. The main disturbing outside factors in the context of the exploited fisheries are fishing activities. 


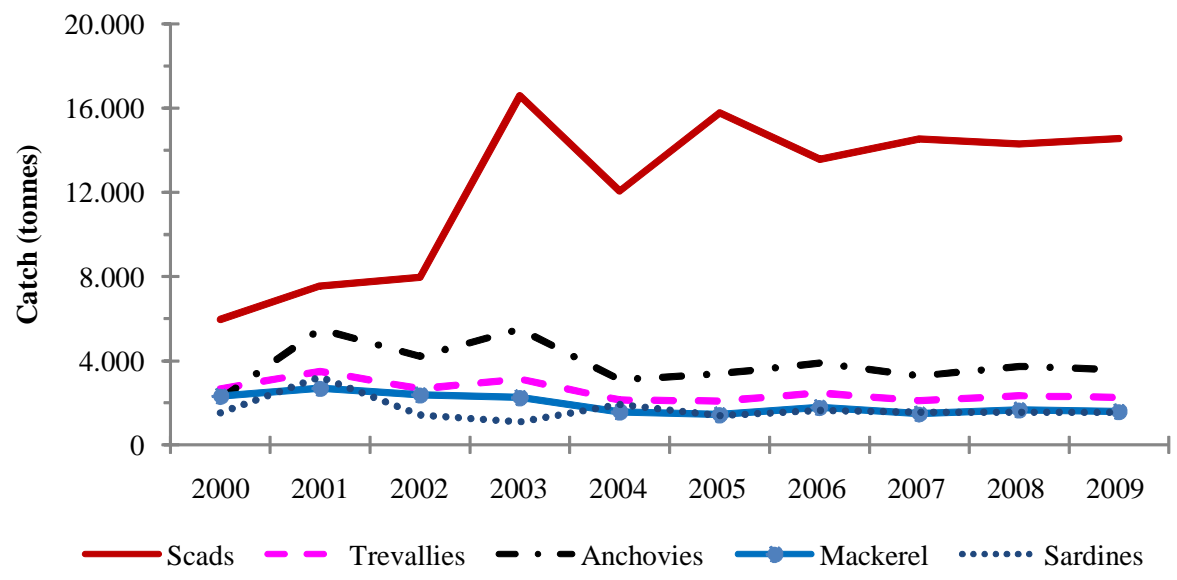

Figure 2. Trend of catch composition of the five species group of the small pelagic in the waters of the Indonesian Sulawesi Sea.

The five species groups of the most economically important fish include scads and trevallies (Carangidae), anchovies (Engraulidae), chub mackerel (Scombridae), and sardines (Clupeidae). Other three dominant species groups with a little lower level of abundance include, flying fish (Exocoetidae), mullets (Mugillidae) and gar-fish (Hemirhampidae). The eight groups of the small pelagic fish are likely forming some species interaction among them, especially in the form of food competition. As be already acknowledged that feeding behaviour of most small pelagic species is plankton feeder. The most vulnerable species from the five groups of the small pelagic fish are likely the sardines group (Sardinella spp.), the mackerels and the trevallies. This was indicated by the relatively low level of the trend of annual production. Between 20002004 the trend of annual production was fluctuated, while in the following year was relatively stable (Figure 2). From the figure it is implied that the small pelagic fish production is dominated by scads, that reflecting the highest level of abundance of the species groups.

\section{DISCUSSION}

Pajeko is the dominant fishing gears used in western part of Sulawesi, away from the Tarakan Bay as they carry out fishing in the bordering waters area with Sabah, Malaysia. There are five species groups of the most economically important fish include scads and trevallies (Carangidae), anchovies (Engraulidae), chub mackerel (Scombridae), and sardines (Clupeidae). From catch composition analysis was implied that the small pelagic fish production is dominated by scads, that reflecting the highest level of abundance of the species groups.

CPUE trend between 2000 - 2009 showed that the highest CPUE of approximately 32 tonnes/pajeko units/year was occurred in 2003 of where total catch and effort was 30,500 tonnes and 956 equivalent pajeko units, respectively. Between 2000-2005, the trend followed the general pattern of the exploited fisheries that already fully exploited, where the increasing trend of effort was not followed by the increasing catch. On the other hand, the trends of catch, effort and CPUE have likely been stable, indicating that the fishery in this period has been level-off.

According to Borsa, (2003) that failed to support Hardenberg's, (1937) hypothesis of three stocks of scad (Decapterus sp.) in the western part of the IndoMalay archipelago. There are three unit stocks of $D$. russelli rested in the Indo-Malay waters, namely: (i) Arafura Sea, (ii) Sulawesi Sea and Makassar Strait and (iii) the rest of the Indo-Malay archipelago. This is the important assumption for assessment of life history and population dynamics of the fish resource in Tarakan Waters.

With regard to the transboundary aspects it is likely that the small pelagic fish stock (especially roundscads, Decapterus spp.) in the waters of Indonesian Sulawesi Sea forming one unit stock. As it is known that the roundscads, shared stock, the most abundance and economically important small pelagic fish. Consequently, this resource has to be collaboratively managed.

Exploitation of pelagic and reef fisheries is also expected to increase, with a shift from local (subsistence) forms of fishing towards commercial, high capital investment forms. The expectation is will provide significant future deterioration, with likely severe socioeconomic hardship, particularly for the majority of the poor rural population (Abdullah et al., 
2003; Licuanan \& Gomez, 2000; Ingles, 2000). It is caused by the rapidly increasing coastal population, level of poverty, greater commercialization, decline in resources, lack of effective regulation and poornonexistent enforcement.

\section{CONCLUSION}

From the analysis of catch and effort data of the small pelagic fisheries by using the surplus yield it revealed that the trend of production (catch), effort and CPUE followed the general pattern of the exploited fisheries that already fully exploited, where the increasing trend of effort was not followed by the increasing catch. On the other hand, the CPUE decreased. In the following years the trends of catch, effort and CPUE have likely been stable, indicating that the fishery in this period has been level-off. It is likely that the present status of exploitation of the small pelagic fish might be already in the state of 'fully exploited'.

The most important aspect that needs to be considered is that the minimum level of CPUE of the gear (pajeko) that fishing activity is still economically profitable. Other aspect that also need to pay attention is that how to maintain optimum level of CPUE. This is due to the fact that if the effort tends to increase it can be expected that CPUE will decrease. The decrease of CPUE will certainly deduct the return of every operated fishing gear unit that finally leads to the bigger loss for every individual fisher.

\section{ACKNOWLEDGEMENTS}

The authors wish to thank the GEF (Sulu-Celebes Sea Sustainable Fisheries Management Project) has funded the research. We also would like to thank the Project Manager Office, the Sulu-Celebes Sea Sustainable Fisheries Management Project and Dr. Annadel S. Cabanban for her invaluable suggestions to this paper.

\section{REFERENCES}

Abdullah, A., Augustina, H., Alcala, A., Alino, P., Bachtiar, I., Bonifacio, R. Cabanban, A., Cheung, C., et al. 2003. Global International Waters Assessment Sulu-Celebes (Sulawesi) Sea Subregion 56 Scaling, Scoping, Causal Chain and Policy Options Analysis. Final Report to GIWA Secretariat, Kalmar University, Sweden. 183 p.

Anonymous., 2001-2011. Capture fisheries statistics of Indonesia. Directorate General of Capture Fisheries. Ministry of Marine Affairs and Fisheries.
Arnaud, S., F. Bonhomme \& P. Borsa. 1999. Mitochondrial DNA analysis of the genetic relationships among populations of scad mackerel (Decapterus macarellus, D. macrosoma, and D. russelli) in South-East Asia. Marine Biology. 135: 699-707.

Borsa, P., 2003. Genetic structure of round scad mackerel Decapterus macrosoma (Carangidae) in the Indo-Malay archipelago. Marine Biology: 142, 575-581.

Chou, L.M. 1997. Southeast Asia as the global center of marine biodiversity. Tropical Coasts. 4: 4-8.

GIWA 2003. http//:www.GIWA.net and http:// www.edc.uri.edu/lme/text

Gulland, J.A, 1983. Fish stock assessment. A manual of basic methods. Vol. 1. John Wiley \& Sons. 223 p.

Ingles, J. 2000. Fisheries of the Calamianes Islands, Palawan Province, Philippines. In: A Rapid Marine Biodiversity Assessment of the Calamianes Islands, Palawan Province, Philippines. Werner, T.B. and Allen, G.R. RAP Bulletin of Biological Assessment 17. Washington DC. Conservation International. p. 45-64.

Kahn, B. \& Fauzi, A. 2001. Fisheries in the Sulu Sulawesi Seas - Indonesian Country Report. Assessment of the State of Biophysical, Socioeconomic, and Institutional Aspects of Coastal and Pelagic Fisheries in the Indonesian Part of the Sulu-Sulawesi Seas. WWF SuluSulawesi Marine Ecoregion Fisheries Project. 166 p.

Licuanan, W.Y. \& Gomez, E.D. 2000. Philippine Coral Reefs, and Associated Fisheries Status and Recommendations to Improve Their Management. Global Coral Reef Monitoring Network. Australia Institute of Marine Science. $44 \mathrm{p}$.

Nurhakim, S., V.P.H.Nikijuluw, D.Nugroho \& B.I.Prisantoso. 2007. Fisheries status in Fisheries Management Areas. Basic information for sustainable exploitation. Research Center for Capture Fisheries. MMAF. $47 \mathrm{p}$ (In Indonesian).

Perrin, C., Borsa, P. 2001. Mitochondrial DNA analysis of the geographic structure of Indian scad mackerel, Decapterus russelli (Carangidae) in the Indo-Malay archipelago. Journal of Fish Biology. $59,1421-1426$. 
Pitcher, T.J. \& P.J.B. Hart, 1982. Fisheries Ecology. Croom Helm. London. 414 p.

Rohfritsch, A. \& P. Borsa. 2005. Genetic structure of Indian scad mackerel Decapterus russelli : Pleistocene vicariance and secondary contact in the Central Indo-West Pacific Seas. Heredity (2005) 95, 315-326.
Ulltang, O., 1977. Methods of measuring stock abundance other than by the use of commercial catch and effort data. FAO Fish. Tech. Pap. No. 176. FAO-UN. Rome. 23 p.

Veron, J.E.N. 2000. Corals of the World. 3 Vols. Australian Institute of Marine Science. 1382 p. 